\title{
Capture Techniques and Morphological Measurements of the Mona Monkey (Cercopithecus mona) on the Island of Grenada, West Indies
}

\author{
MARY E. GLENN* ANI KEITH J. BENSEN \\ Windward Islands Research and Education Foundation. \\ Bayshore, New York 11706
}

KEY WORDS guenon; Caribbean; morphometrics; sexual dimorphism; Ketaset; Rompun

\begin{abstract}
Morphological measurements were collected from 12 wild and 12 captive mona monkeys (Cercopithecus mona) on the Caribbean island of Grenada. Mona monkeys were introduced to Grenada from Africa approximately 200 to 300 years ago during the slave trade era. Wild monkeys were captured using either 1) a baited treadle-door trap and anesthetic-filled darts fired from a blowpipe, or 2) rifle-fired anesthetic-filled darts. All wild monkeys were released back into the forest after capture and were seen with their original groups within 24 hours of release. Captive monkeys were anesthetized using blowpipe-fired darts. A Ketaset/Rompun mixture was the most effective anesthetic for wild monkeys while Ketaset alone was suitable for captive monkeys. Responses to and recovery times from both drugs varied among individuals. Data on eight linear body measurements, canine length, testicle size, and weight were collected from all monkeys. Adult monkeys were significantly sexually dimorphic across all measurements. Mean adult male weight $(\overline{\mathrm{x}}=4.7, \mathrm{SD}=0.9, \mathrm{n}=13$ ) was almost twice that of adult females $(\overline{\mathrm{x}}=2.8, \mathrm{SD}=0.8, \mathrm{n}=7)$. No significant differences in weight or measurements were found between adult wild and captive males. Preliminary comparisons with morphometrics for African C. mona from the literature showed the upper limit of Grenada mona body length and weight to be smaller than that of African monas for both sexes. These differences may be due to genetic divergence, ecological adaptation, inter-African geographic variation, and/or small sample sizes. Am J Phys Anthropol 105:481-491, 1998.
\end{abstract}

a: 199 wile $y-J$ Liss, Inc.

The mona monkey (Cercopithecus mona) is a little studied, medium-sized arboreal guenon whose range in mainland Africa lies between eastern Ghana and southwest Cameroon (Booth, 1955, 1956; Hill, 1966; Oates, 1988). Introduced populations of C. mona are found on the African islands of São Tomé and Príncipe in the Gulf of Guinea (Frade, 1958). The mona monkey was also introduced to the Caribbean island of Grenada (Fig. 1) sometime between the late 17th and 18 th centuries during the height of the African slave trade to the Americas (Glenn,
1996). During this time, the transport of exotic animals from Africa for trade as pets was common, although usually only a small number of animals were carried as cargo at

\footnotetext{
Contract grant sponsors: Windward lslands Reseurch and Education Foundation: The Rockefeller University; The Yerkes Regional Primate Research Center; The Foundation for Field Regional Primate Research Center; The Foundation for Field
Research; Sigma Xi:-The Scientific Research Society; 'The Researeh Grants Committec of Northwestern University.

"Correspondence to: Mary E. Glenn, Windward Islands Rescarch and Education Foundation, 11 East Main Street, Suite 154, Bayshore, NY 11706. Fax: (516) 968-1321.

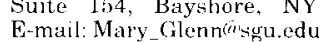

Received 18 April 1997; accepted 22 November 1997
} 
one time (Eaden, 1931; Denham, 1982, 1987). Since its introduction to Grenada, the mona monkey has become naturalized and greatly increased in number on the island (Glenn, in press).

No comprehensive studies of the mona monkey had been made, either in its original African range or in its introduced island ranges, previous to the authors' study of the Grenada C. mona population (e.g., Glenn and Bensen, 1993; Glenn, 1996, 1997). The morphology of mona monkeys on Grenada had never before been described, and morphological data from African populations of C. mona are scattered and few. None of the information currently available in the literature on the morphology of African mona monkeys was obtained from large sample sizes or constitutes a complete set of weight and body measurements from one population.

In addition, while data regarding capture methods for Old World terrestrial monkeys (Brett et al., 1982; Pearl, 1982; Horrocks and Baulu, 1988), lemurs (Glander et al., 1992), and New World primates (Scott et al., 1976; Glander et al., 1991; Lemos de Sa and Glander, 1993; Savage et al., 1993; Campbell and Sussman, 1994; Müller and Schildger, 1994) are numerous, only one paper describes capture techniques for an arboreal Old World monkey (Jones and Bush, 1988).

This paper provides morphological measurements for C. mona on Grenada, as well as information on their capture and release. The morphometrics presented here provide baseline information to which that of other populations of $C$. mona may be compared. Morphological data collected from a longisolated population of guenons founded by a few individuals are valuable; when compared to those from the parent population, any morphological differences or similarities found may provide clues as to what changes, if any, may be expected in the first 100 generations of isolation of a small guenon population.

\section{MATERIALS AND METHODS Capture}

Morphological measurements were collected from 12 wild and 12 captive mona monkeys ( 13 adult males, 3 subadult males, 7 adult females, and 1 subadult female) between 28 April 1993 and 19 March 1995. Eight wild monkeys were captured near the field research station, a small house surrounded by forest and located in the center of the 1,540-ha Grand Etang National Park and Forest Reserve $\left(12^{\circ} 6^{\prime} \mathrm{N}, 61^{\circ} 42^{\prime} \mathrm{S}\right)$ (Fig. 1).

Three of the wild monkeys were captured by placing a treadle-door trap baited with bananas near the edge of the forest at the field research station. Once inside the trap, monkeys were anesthetized with 0.8 to 1.0 $\mathrm{ml}$ Ketaset (ketamine hydrochloride, 100 $\mathrm{mg} / \mathrm{ml}$; Bristol Laboratories, Syracuse, NY) ejected from a blowpipe (Pneu Dart, Inc., Williamsport, PA) in a 1-ml, nonbarbed, disposable dart with a $12.7 \mathrm{~mm}$ needle. Ketaset was chosen because of its effectiveness and safety (more than six times the dose may be given without harming an animal) (Glander et al., 1991). Further injections of Ketaset were given if the monkey recovered from the original dose of anesthetic before handling was complete.

Five of the wild monkeys were captured while in trees using a .22-caliber cartridgefired darting rifle and nonbarbed, anestheticfilled, disposable 1-ml darts with $12.7 \mathrm{~mm}$ needles (Pneu Dart, Inc., Williamsport, PA). Release of the drug (for blowpipe and rifle darts) occurred upon contact when a charge within the dart was set off. The darts were loaded with a 5:1 mixture of Ketaset and Rompun (xylazine, $20 \mathrm{mg} / \mathrm{ml}$; Bayer Corp., Shawnee Mission, KS) with a dose of approximately $0.2 \mathrm{ml}$ per estimated $\mathrm{kg}$ body weight (Jones and Bush, 1988). Rompun, a muscle relaxant, was used in conjunction with Ketaset to dart monkeys in trees so that they would release their grip on the branches and fall to the ground (Huntsman, personal communication). Additional doses of Ketaset were given if monkeys began to recover from the anesthetic before measuring procedures were complete. Mona monkeys are active and nervous animals, and were difficult darting targets in dense forest foliage. Thus, all darting attempts were done in the last year of the study when animals were most habituated; these were limited to monkeys within $20 \mathrm{~m}$ and in postures in which a good 


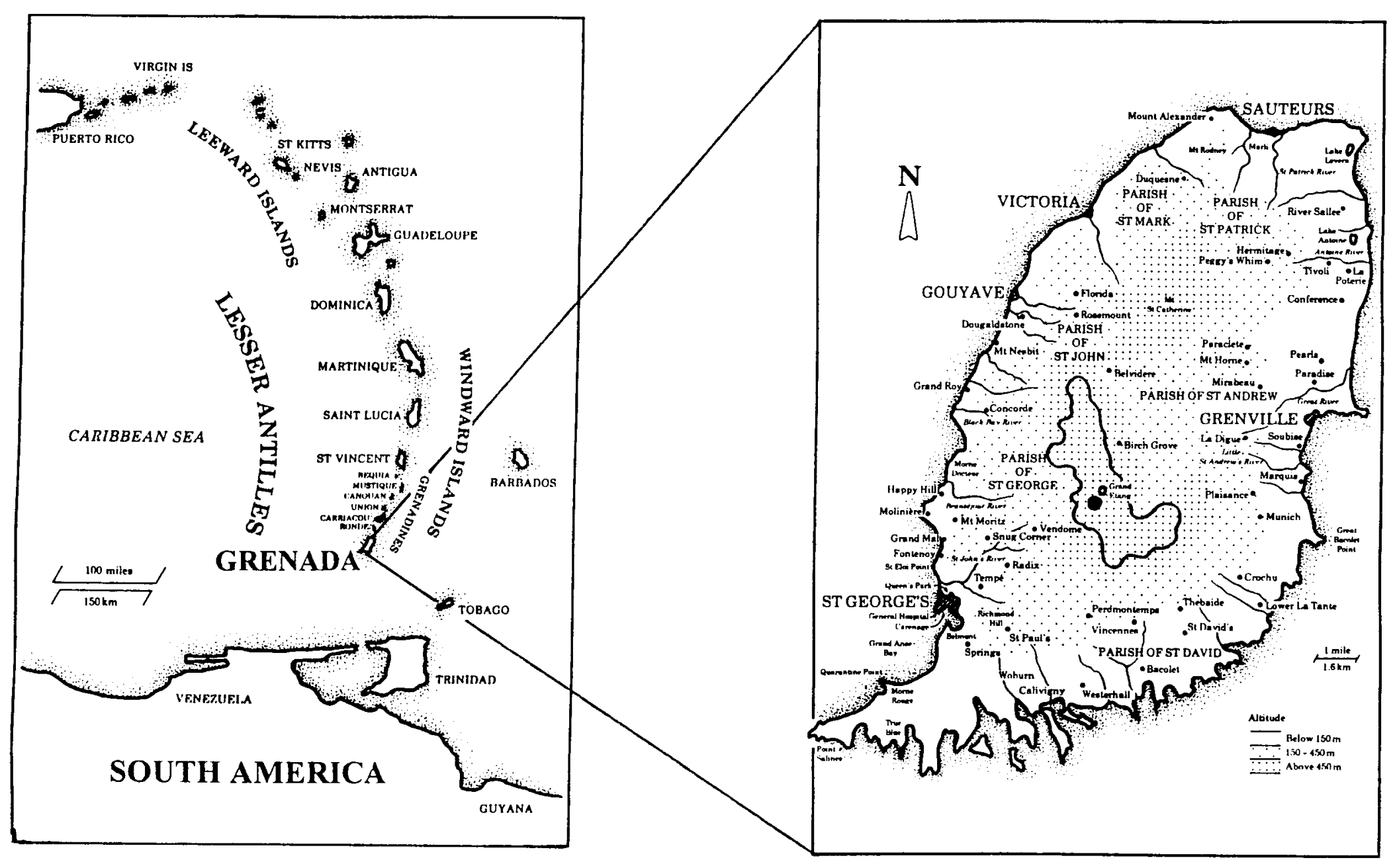

Fig. 1. Location of the island of Grenada, the Grand Etang National Park and Forest Reserve (indicated by the solid-lined polygon) and field station (indicated by dot). 
shot at the thigh or rump was possible. Scott et al. (1976) and Glander et al. (1991) recommended catching falling monkeys with a net; however, this was impractical at Grand Etang because the understory was too dense in most places to spread a net. Therefore, monkeys were not darted unless sitting on branches less than $6 \mathrm{~m}$ from the ground. Once captured and anesthetized, monkeys were measured, released into the forest and supervised until full recovery from the anesthetic was evident (i.e., when the monkey could walk and climb with full muscle coordination).

Four of the 12 wild samples were recently shot monkeys obtained from hunters from outside the study area. Carcasses were weighed, measured and immediately returned to the hunter.

Captive monkeys were found island-wide. One of the 12 captive samples came from a monkey in the local zoo, which was released into the forest after it was measured and fully recovered from the anesthetic. The remaining captive monkeys were pets. All pet owners had acquired their monkeys as infants or young juveniles, usually purchased from hunters who had shot down a female with a surviving clinging infant. All of the pets were housed in cages; only two of the 12 pets were occasionally let out on a chain for exercise. Captive monkeys were anesthetized in the same manner as the trap-captured wild monkeys.

Mean immobilization and recovery time between Ketaset and Ketaset/Rompun, and mean effective dose between captive and wild monkeys were compared using MannWhitley U tests (two-tailed). The alpha level was set at 0.05 .

\section{Measuring}

Monkeys were weighed by placing them in a small nylon mesh net suspended from a 10-kg Pesola spring scale (Pesola Corp., Zurich, Switzerland). Body measurements were taken to the nearest $\mathrm{mm}$ with a $5-\mathrm{m}$ metal tape (see Table 1 for a description of measurements). Canine length and testicle length and width were taken with a vernier caliper. Testicular volume was calculated using the formula for an ellipsoid, or $4 / 3 \mathrm{pi}$ $[(0.5 \mathrm{~L})(0.5 \mathrm{~W})]^{2}$ (Nadler and Rosenblum,
TABLE 1. Description of morphological measurements (from Glander et al.. 1991)

Tail length is measured on the ventral side from the tip of the tail (excluding the hair) to the junction of the base of the tail with the perianal area. The tail is completely extended straight out behind the animal.

Body length is determined by subtracting Tail length from Tail-crown length, which is measured from the tip of the tail to the most anterior point on the head in normal position (i.e., chin near the chest i.

Hindleg length is measured from the groin to the end of the longest digit, excluding the nail.

Hindfoot length is measured from the heel to the end of the longest digit, excluding the nail.

Big toe length is measured from the junction of skin and big toe to the tip of the big toe excluding the nail when the big toe is extended perpendicular to the other digits.

Foreleg length is measured from the axillary region to the tip of the longest digit, excluding the nail.

Forefoot length is measured from the proximal edge of the friction pad nearest the wrist to the tip of the longest digit, excluding the nail.

Thumb length is measured from the junction between the first and second digits to the tip of the thumb. excluding the nail.

Testicle width and length are measured with a vernier caliper.

Maxillary and mandibular canine lensths are measured from the cementum-enamel junction to the apex of the canine with a vernier caliper.

1972; Glander et al., 1991, 1992). Left and right testicular volumes were summed for total testicular volume. All weights and measurements were taken twice to insure accuracy. Age was estimated based on tooth eruption for both sexes, and nipple length for females. Males with fully erupted third molars and canines were considered adult; males whose third molars had erupted but whose canines were not fully erupted were considered subadult (Cope, personal communication). Females with fully erupted third molars and/or pendulant nipples (indicating a previous pregnancy) (Struhsaker, 1969) were classified as adult. The following age class estimates were used, based on knowledge gained from observations of captive and wild mona monkeys' ages and development: adult (males, $\geq 5$ years; females, $\geq 4$ years), subadult (males, $3-4$ years; females, 2-3 years ). No juveniles or infants are represented in this sample. Means for total testicular volumes, weights and linear measurements were compared using Mann-Whitley $\mathrm{U}$ tests (two-tailed). The alpha level was set at 0.05 . 
TABLE 2. Capture methods, drug doses, and recovery times

\begin{tabular}{|c|c|c|c|c|c|c|c|c|}
\hline No. & $\begin{array}{l}\text { Age/ } \\
\text { sex }\end{array}$ & Status & $\begin{array}{l}\text { Weight } \\
\text { (kg) }\end{array}$ & $\begin{array}{l}\text { Capture } \\
\text { method }\end{array}$ & $\begin{array}{c}\text { Dose in } \\
\text { dart (ml) }\end{array}$ & $\begin{array}{l}\text { Time to } \\
\text { fall/stop } \\
\text { moving } \\
\text { (minutes) }\end{array}$ & $\begin{array}{c}\text { Additional } \\
\text { injections } \\
\text { (Ketaset } \\
\text { only })(\mathrm{m} 1)\end{array}$ & $\begin{array}{c}\text { Recovery } \\
\text { (hours) }\end{array}$ \\
\hline 01 & $\mathrm{AM}$ & $\mathrm{W}$ & 5.70 & $\mathrm{DR}$ & 0.8 Ketaset/Rompun & 2.5 & None & 3.3 \\
\hline 02 & $\mathrm{AM}$ & $\mathrm{C}$ & 5.60 & $\mathrm{PC} / \mathrm{BP}$ & 1.0 Ketaset & 6.5 & 0.8 & Unknown \\
\hline 03 & $\mathrm{AM}$ & $\mathrm{C}$ & 5.40 & $\mathrm{PC} / \mathrm{BP}$ & 1.0 Ketaset & 8.0 & 1.0 & Unknown \\
\hline 04 & $\mathrm{AM}$ & W & 5.30 & $\mathrm{TDT} / \mathrm{BP}$ & 0.8 Ketaset & 2.0 & None & 2.0 \\
\hline 05 & AM & $\mathrm{C}$ & 5.30 & $\mathrm{PC} / \mathrm{BP}$ & 0.9 Ketaset & 4.0 & None & 2.8 \\
\hline 06 & AM & $\mathrm{W}$ & 5.30 & $\mathrm{DR}$ & 1.0 Ketaset/Rompun & 3.0 & None & 2.0 \\
\hline 07 & $\mathrm{AM}$ & W & 4.90 & $\mathrm{SH}$ & - & - & - & - \\
\hline 08 & $\mathrm{AM}$ & W & 4.60 & DR & 1.0 Ketaset/Rompun & 1.5 & $0.2,0.6$ & 2.8 \\
\hline 09 & $\mathrm{AM}$ & W & 4.60 & $\mathrm{DR}$ & 1.0 Ketaset/Rompun & 5.5 & None & 4.5 \\
\hline 10 & AM & $\mathrm{C}$ & 4.00 & $\mathrm{PC} / \mathrm{BP}$ & 1.0 Ketaset & 3.5 & 0.5 & Unknown \\
\hline 11 & AM & $\mathrm{C}$ & 3.80 & $\mathrm{PC} / \mathrm{BP}$ & 1.0 Ketaset & 4.5 & None & Unknown \\
\hline 12 & $\mathrm{AM}$ & C & 3.30 & $\mathrm{PC} / \mathrm{BP}$ & 1.0 Ketaset & 7.0 & 0.5 & Unknown \\
\hline 13 & $\mathrm{AM}$ & C & 3.20 & $\mathrm{PC} / \mathrm{BP}$ & 1.0 Ketaset & 1.0 & None & Unknown \\
\hline 14 & SaM & W & 4.10 & $\mathrm{TD} T / \mathrm{BP}$ & 0.8 Ketaset & 1.0 & None & 2.8 \\
\hline 15 & $\mathrm{SaM}$ & W & 4.00 & DR & 1.0 Ketaset/Rompun & 2.2 & None & 2.3 \\
\hline 16 & $\mathrm{SaM}$ & W & 3.30 & ТD'Т/BP & 1.0 Ketaset & 3.5 & $0.2,0.4$ & 1.5 \\
\hline 17 & $\mathrm{AF}^{2}$ & $\mathrm{C}$ & 4.30 & $\mathrm{PC} / \mathrm{BP}$ & 1.0 Ketaset & 5.0 & 1.0 & Unknown \\
\hline 18 & $\mathrm{AF}$ & W & 3.25 & $\mathrm{SH}$ & - & - & - & - \\
\hline 19 & $\mathrm{AF}$ & W & 3.00 & $\mathrm{SH}$ & - & - & - & - \\
\hline 20 & $\mathrm{AF}$ & W & 2.65 & $\mathrm{SH}$ & - & - & - & - \\
\hline 21 & $\mathrm{AF}$ & $\mathrm{C}$ & 2.30 & $\mathrm{PC} / \mathrm{BP}$ & 1.0 Ketaset & 2.8 & 0.8 & Unknown \\
\hline 22 & $\mathrm{AF}$ & $C$ & 2.30 & $\mathrm{PC} / \mathrm{BP}^{2}$ & 1.0 Ketaset & 5.5 & None & Unknown \\
\hline 23 & $\mathrm{AF}$ & $\mathrm{C}$ & 2.10 & $\mathrm{PC} / \mathrm{BP}$ & 0.8 Ketaset & 3.0 & None & Unknown \\
\hline 24 & $\mathrm{SaF}$ & $\mathrm{C}$ & 1.50 & $\mathrm{PC} / \mathrm{BI}^{3}$ & 0.7 Ketaset & 1.5 & 0.5 & Unknown \\
\hline
\end{tabular}

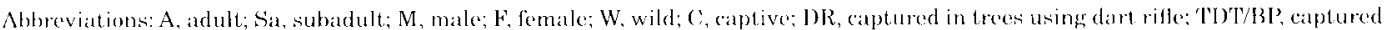
in tradle-dior trap and inesthetized with blowpipe; SH, shot by hunter; PC/BP, pet in cage anesthetized with blowpipe.

\section{RESULTS \\ Capture}

Table 2 presents the capture methods, drug doses and recovery times for each monkey in the sample. A mean dose of 0.96 $\mathrm{ml}(\mathrm{SD}=0.9, \mathrm{n}=5)$ of the Ketaset/Rompun mixture caused darted wild monkeys to fall from the trees in an average of 2.9 minutes $(\mathrm{SD}=1.5, \mathrm{n}=5)$; a mean dose of $0.93 \mathrm{ml}$ ( $\mathrm{SD}=0.1, \mathrm{n}=15$ ) of Ketaset immobilized captive and trap-captured wild monkeys in an average of 3.9 minutes $(\mathrm{SD}=2.2, \mathrm{n}=15$ ). The differences in mean immobilization time between straight Ketaset and the Ketaset/ Rompun mixture were not significant ( $\mathrm{Z}=-0.85, \mathrm{n}=20, P=0.40)$. Additional injections of Ketaset were necessary for one monkey anesthetized with Ketaset/Rompun and for eight monkeys anesthetized with Ketaset only. The average time to additional injections was 13.5 minutes $(\mathrm{SD}=7.3$, $\mathrm{n}=9$ ). No significant differences were found for the effective dose of Ketaset $(\mathrm{Z}=-0.29$, $\mathrm{n}=15, P=0.78$ ) and the time to immobilization ( $\mathrm{Z}=-1.55, \mathrm{n}=15, P=0.12)$ between the trap-captured wild monkeys and captive monkeys.
Responses to both drugs varied among individuals (Table 2), but some of this variation may be attributed to partial injections of the drug. If a dart did not hit perpendicular to the target, a complete injection of the drug would not occur. Differences in immobilization time also appeared to be affected by the location of the target. On one occasion, the dart missed the well-muscled part of the hindquarters and hit the knee of a monkey, possibly resulting in a longer immobilization time ( 5.5 minutes, Ketaset/Rompun). In addition, two wild monkeys that appeared to have been darted showed no effect from the Ketaset/Rompun mixture. These failures may have been due to faulty charges in the darts or partial injection of the drug from a missed target or improperly fired dart. If fired too hard, darts would bounce out too quickly without having time to inject a full dose of the anesthetic.

The use of Ketaset alone was not effective when darting monkeys in trees. One wild monkey was darted with Ketaset only; it was immobilized but did not fall from the trees because it did not release its grip on the branches. 
The distance to the target varied from 4 to $20 \mathrm{~m}$ when darting monkeys in trees. The height of the monkeys when darted ranged from 2.5 to $6 \mathrm{~m}$. Reactions of darted monkeys varied: some fled from sight while others moved only a small distance away and then examined their wounds. On all occasions, monkeys climbed higher in the trees when darted. Heights of falls ranged from 5 to $15 \mathrm{~m}$, with a mean of $6.5 \mathrm{~m}$ $(\mathrm{SD}=4.9, \mathrm{n}=5)$. None of the wild monkeys was injured from a fall, possibly because of the thick understory.

The reactions of other group members of wild monkeys to capture procedures were mixed. During capture with the treadle-door trap, other group members would stay and watch and begin to alarm call only when the monkey in the trap was darted. No group member that had observed the procedure would then enter the trap when it was next set up; the three monkeys captured in this manner were from different groups. During capture with the dart rifle, most group members would silently and quickly flee when the rifle was fired, but would return minutes later. Both monkeys that were darted and those that had watched the darting procedure would later flee in the presence of the darter, but not in the presence of other observers.

Recovery from Ketaset/Rompun took an average of 3.0 hours ( $\mathrm{SD}=1.0, \mathrm{n}=5$ ) for monkeys captured with the dart rifle. In the wild trap-captured monkeys and the zoo monkey, recovery from Ketaset averaged 2.3 hours ( $\mathrm{SD}=0.6, \mathrm{n}=4$ ). Recovery times between the two drugs were not significantly $\operatorname{different}(\mathrm{Z}=-1.23, \mathbf{n}=9, P=0.22)$. Recovery times for pet monkeys were not recorded. Pets were observed until moving and showing signs of cognizance, but were left before full muscle coordination was achieved. Follow-up visits or telephone calls were made to pet owners; none reported a full recovery time of more than 4 hours. Neither wildcaught nor captive monkeys suffered any interference with their ability to thermalregulate with either Ketaset or Ketaset/ Rompun, and no monkeys were injured during the capture procedures. All wild monkeys were seen with their original group within 24 hours of capture.

\section{Morphometrics}

Table 3 presents the weight and measurements of each captured monkey. Adults were significantly sexually dimorphic for body weight and all linear measurements (Table 4). Mean weight for adult males was almost twice that of adult females, although the heaviest two adult females weighed more than the lightest adult males. However, the heaviest female was an overfed pet and the second heaviest female was pregnant, which may account for them weighing more than the lightest adult males. No adult female had a greater measurement than any adult male for body, tail, hindleg, foreleg, forefoot and maxillary and mandibular canine lengths. The average intermembral indices (foreleg minus forefoot/hindleg minus hindfoot) were 89 for both males $(\mathrm{CV}=5.50)$ and females $(\mathrm{CV}=3.25)$. Hindlegs were significantly longer than forelegs in all age and sex classes represented in this sample $(\mathrm{Z}=-3.90, \mathrm{n}=24, P=0.00008)$.

No significant differences in weight or measurements were found between adult wild and captive male monas (Table 5). Testicular volume was bilaterally similar in both wild and captive males $(\mathrm{Z}=-0.28$, $\mathrm{n}=32, P=0.74)$. Morphometrics for wild and captive females were not compared because two of the three wild adult females in the sample were pregnant at the time of capture.

\section{DISCUSSION Effectiveness of capture drugs}

Aside from safety, the most important factor in the consideration of a capture drug for wild animals is its ability to immobilize an animal quickly so that the animal cannot get away. Results from this and other studies have shown that Ketaset alone is an ineffective capture drug when darting monkeys in trees (Glander et al., 1991). The addition of a muscle relaxant (Rompun) was needed in order to prevent monkeys from falling asleep while still grasping onto tree branches. Ketaset alone proved an effective drug for anesthetizing caged animals even though its use required more additional injections to keep an animal under anesthesia while processing than did the Ketaset/ 
TABLE 3. Morphometrics of Cercopithecus mona on Grenada

\begin{tabular}{|c|c|c|c|c|c|c|c|c|c|c|c|c|c|c|}
\hline \multirow[b]{2}{*}{ No. } & \multirow[b]{2}{*}{$\begin{array}{l}\text { Age/ } \\
\text { sex }\end{array}$} & \multirow[b]{2}{*}{ Status } & \multirow[b]{2}{*}{$\begin{array}{c}\text { Weight } \\
\text { (kg) }\end{array}$} & \multirow{2}{*}{ Body } & \multirow[b]{2}{*}{ Tail } & \multirow[b]{2}{*}{$\begin{array}{c}\text { Hind } \\
\text { leg }\end{array}$} & \multirow[b]{2}{*}{$\begin{array}{l}\text { Hind } \\
\text { foot }\end{array}$} & \multicolumn{4}{|c|}{ Length (mm) } & \multirow[b]{2}{*}{$\begin{array}{c}\text { Canine } \\
\text { maxillary }\end{array}$} & \multirow[b]{2}{*}{$\begin{array}{c}\text { Canine } \\
\text { mandibular }\end{array}$} & \multirow{2}{*}{$\begin{array}{c}\text { Total } \\
\text { testicular } \\
\text { volume } \\
\left(\mathrm{mm}^{3}\right)\end{array}$} \\
\hline & & & & & & & & $\begin{array}{l}\text { Big } \\
\text { toe }\end{array}$ & $\begin{array}{c}\text { Fore } \\
\text { leg }\end{array}$ & $\begin{array}{l}\text { Fore } \\
\text { foot }\end{array}$ & Thumb & & & \\
\hline 01 & $\mathrm{AM}$ & W & 5.70 & 488 & 652 & 380 & 132 & 25 & 307 & 91 & 18 & 18.0 & 13.5 & 108906.4 \\
\hline 02 & $\mathrm{AM}$ & $\mathrm{C}$ & 5.60 & 466 & 700 & 424 & 141 & 27 & 323 & 92 & 18 & 20.0 & 8.0 & 67503.5 \\
\hline 03 & $\mathrm{AM}$ & $\mathrm{C}$ & 5.40 & 515 & 730 & 418 & 136 & 25 & 325 & 97 & 18 & 21.0 & 13.0 & 70641.1 \\
\hline 04 & $\mathrm{AM}$ & W & 5.30 & 512 & 700 & 407 & 135 & 21 & 347 & 96 & 18 & 15.5 & 11.5 & 96454.8 \\
\hline 05 & $\mathrm{AM}$ & $\mathrm{C}$ & 5.30 & 470 & 660 & 372 & 132 & 21 & 318 & 86 & 14 & 18.0 & 10.0 & 133040.8 \\
\hline 06 & $\mathrm{AM}$ & W & 5.30 & 480 & 570 & 384 & 130 & 23 & 315 & 88 & 18 & 19.0 & 12.5 & 71945.1 \\
\hline 07 & $\mathrm{AM}$ & $\mathrm{W}$ & 4.90 & 510 & 725 & 427 & ] 43 & 26 & 347 & 98 & 21 & 15.0 & 12.0 & 55549.1 \\
\hline 08 & $\mathrm{AM}$ & W & 4.60 & 480 & 645 & 376 & 132 & 22 & 307 & 89 & 17 & 18.0 & 12.0 & 33348.5 \\
\hline 09 & $\mathrm{AM}$ & W & 4.60 & 459 & 666 & 368 & 133 & 20 & 295 & 77 & 17 & 12.0 & 10.0 & 64894.8 \\
\hline 10 & AM & $\mathrm{C}$ & 4.00 & 438 & 705 & 375 & 130 & 25 & 321 & 91 & 17 & 21.0 & 13.5 & 30199.4 \\
\hline 11. & $\mathrm{AM}$ & C & 3.80 & 445 & 665 & 390 & 135 & 23 & 310 & 85 & 20 & 15.0 & 11.0 & 8091.0 \\
\hline 12 & $\mathrm{AM}$ & $\mathrm{C}$ & 3.30 & 455 & 645 & 410 & 127 & 17 & 321 & 87 & 19 & 16.0 & 10.0 & 48402.8 \\
\hline 13 & $\mathrm{AM}$ & C & 3.20 & 435 & 643 & 380 & 130 & 22 & 313 & 88 & 15 & 16.5 & 10.5 & 45415.0 \\
\hline 14 & $\mathrm{SaM}$ & W & 4.10 & 430 & 645 & 359 & 130 & 20 & 303 & 86 & 21 & 7.0 & 10.5 & 31953.4 \\
\hline 15 & $\mathrm{SaM}$ & W & 4.00 & 456 & 638 & 393 & 129 & 19 & 315 & 87 & 18 & 13.0 & 9.5 & 17759.6 \\
\hline 16 & SaM & W & 3.30 & 402 & 585 & 350 & 120 & 21 & 280 & 91 & 15 & 7.0 & 9.5 & 26279.6 \\
\hline 17 & $\mathrm{AF}$ & $\mathrm{C}$ & 4.30 & 405 & 540 & 350 & 118 & 17 & 270 & 77 & 16 & 6.0 & 3.5 & \\
\hline $18^{1}$ & $\mathrm{AF}$ & W & 3.25 & 405 & 560 & 350 & 115 & 23 & 295 & 81 & 16 & 7.5 & 6.0 & \\
\hline 19 & $\mathrm{AF}$ & W & 3.00 & 422 & 576 & 351 & 128 & 20 & 269 & 68 & 17 & 6.5 & 6.0 & \\
\hline $20^{1}$ & $\mathrm{AF}$ & W & 2.65 & 396 & 569 & 330 & 109 & 17 & 274 & 76 & 15 & 7.0 & 6.0 & \\
\hline 21 & $\mathrm{AF}$ & $\mathrm{C}$ & 2.30 & 341 & 524 & 311 & 105 & 16 & 256 & 68 & 14 & 4.5 & 4.5 & \\
\hline 22 & $\mathrm{AF}$ & $\mathrm{C}$ & 2.30 & 355 & 620 & 360 & 115 & 19 & 285 & 75 & 15 & 9.0 & 6.0 & \\
\hline 23 & $\mathrm{AF}$ & $C$ & 2.10 & 346 & 549 & 335 & 110 & 22 & 275 & 71 & 15 & 7.0 & 4.5 & \\
\hline 24 & $\mathrm{SaF}$ & $\mathrm{C}$ & 1.50 & 374 & 435 & 315 & 113 & 19 & 256 & 76 & 15 & 4.5 & 5.5 & \\
\hline
\end{tabular}

Abbreviations: A, adult; Sa, subadult; M, male; F, female; W, wild; C, captive.

1 Pregrant at time of capture.

Rompun mixture. The use of Rompun, however, should be limited to situations which require full relaxation of muscles (i.e., darting wild monkeys) because the safety margin for doses of Ketaset/Rompun is much lower than that for Ketaset alone (Huntsman, personal communication).

Contrary to the findings of Glander et al. (1991), the effective dose of Ketaset for captive monkeys was not lower than that for wild monkeys. Glander et al. (1991) reported using doses for wild New World monkeys from 5 to 30 times the doses used to effectively anesthetize captive monkeys; no such differences were found between captive and wild C. mona on Grenada.

\section{Captive vs. wild morphometrics}

Surprisingly, weights and linear dimensions were not significantly different between adult wild and captive male monas on Grenada, even though the captive monkeys had reduced muscle tone and were in much poorer health than the wild monkeys. All

TABLE H. Morphometric means (SD in parentheses) for adults and results of male-female comparison Mann-Whitley Utest)

\begin{tabular}{|c|c|c|c|c|}
\hline & $\begin{array}{c}\text { Males } \\
(\mathrm{n}-13)\end{array}$ & $\begin{array}{c}\text { Females } \\
\left(n^{-\cdots} 7\right)\end{array}$ & $\mathrm{Z}$ & $P$ \\
\hline Weight ( $\mathrm{kg}$ ) & $4.7(0.9)$ & $2.8(0.8)$ & -3.22 & 0.001 \\
\hline Body (mm) & $473.3(27.4)$ & $381.4(33.1)$ & -3.61 & 0.0003 \\
\hline Tail (mm) & $669.7(42.9)$ & $562.6(30.8)$ & 3.44 & 0.0006 \\
\hline Hindleg (mm) & $393.2(21.1\}$ & $341.0(16.7)$ & -3.61 & 0.0003 \\
\hline Hind foot ( $\mathrm{mm})$ & $133.5(4.5)$ & $114.3(7.5)$ & -3.54 & 0.0004 \\
\hline Big toe (mm) & $22.9(2.8)$ & $19.1(2.7)$ & -2.40 & 0.017 \\
\hline Foreleg (mm) & $319.2(14.8)$ & $274.9(12.4)$ & -3.57 & 0.0004 \\
\hline Forefoot ( $\mathrm{mm}$ ) & $89.6(5.6)$ & $73.7(4.9)$ & -3.49 & 0.0005 \\
\hline Thumb (mm) & $17.7(1.8)$ & $15.4(1.0)$ & -2.66 & 0.008 \\
\hline Canine, maxillary (mm) & $17.3(2.6)$ & $6.8(1.4)$ & -3.68 & 0.0002 \\
\hline Canine, mandibular ( $\mathrm{mm})$ & $11.4(1.6)$ & $5.2(1.0)$ & -3.88 & 0.0001 \\
\hline Testicular volume $\left(\mathrm{mm}^{3}\right)$ & $64,184.0(33,941.5)$ & & & \\
\hline
\end{tabular}


TABLE 5. Morphometric means (SD in parentheses) for adult male wild and captive individuals and results of uild-captive comparison Mann-Whitley U test!

\begin{tabular}{|c|c|c|c|c|}
\hline & $\begin{array}{c}\text { Wild } \\
(\mathrm{n}=6)\end{array}$ & $\begin{array}{c}\text { Captive } \\
(\mathrm{n}-7)\end{array}$ & Z & $P$ \\
\hline Weight (kg) & $5.1(0.4)$ & $4.4(1.0)$ & 1.01 & 0.31 \\
\hline Body $(\mathrm{mm})$ & $488.2(20.1)$ & $460.6(27.4)$ & -1.82 & 0.07 \\
\hline Tail (mm) & $659.7(53.4)$ & $678.3(33.5)$ & -0.37 & 0.71 \\
\hline Hindleg (mm) & $390.3(22.2)$ & $395.6(21.5)$ & 0.29 & 0.77 \\
\hline Hindfoot ( $\mathrm{mm}$ ) & $134.2(4.6)$ & $133.0(4.7)$ & -0.51 & 0.61 \\
\hline Big toe $(\mathrm{mm})$ & $22.8(2.3)$ & $22.9(3.3)$ & 0.16 & 0.87 \\
\hline Foreleg (mm) & $319.7(22.1)$ & $318.7(5.4)$ & 0.68 & 0.50 \\
\hline Forefoot $(\mathrm{mm})$ & $89.8(7.4)$ & $89.4(4.2)$ & -0.52 & 0.60 \\
\hline Thumb ( $\mathrm{mm}$ ) & $18.2(1.5)$ & $17.3(2.1)$ & -0.78 & 0.43 \\
\hline Canine, maxillary (mm) & $16.3(2.6)$ & $18.2(2.5)$ & -1.28 & 0.20 \\
\hline Canine, mandibular ( $\mathrm{mm}$ ) & $11.9(1.2)$ & $10.9(1.9)$ & 1.11 & 0.26 \\
\hline Testicular volume ( $\left.\mathrm{mm}^{3}\right)$ & $71,849.8(27,177.4)$ & $57,613.4(39,569.4)$ & 0.92 & 0.35 \\
\hline
\end{tabular}

captive monkeys in this sample had been caged at a very early age, and most were malnourished and dehydrated (although one pet in the sample, no. 17 in Table 3, was extremely overfed). Thus, it appears that both lifetime confinement and an altered diet did not significantly affect the outcome of adult body weight and measurements in captive male mona monkeys on Grenada.

Leigh (1994) also found that the captive and noncaptive weights for the adult anthropoid primates in his study were generally highly correlated. He stated that he did not expect to find dramatic differences between captive and wild weights because "conditions experienced in the 'wild' are highly variable," and thus, responses to these conditions would result in a wide range of "normal" weights for adult wild nonhuman primates. Gautier-Hion and Gautier (1976), on the other hand, found that their captiveraised Cercopithecus monkeys from several species tended to be heavier than the captives'wild-caught conspecifics. These conflicting findings concerning the effects of captivity on various nonhuman primates' adult morphology may reflect differences both in captive care and conditions in the wild, and indicate a need for additional comparative morphological data on captive and wild nonhuman primate species.

\section{Comparisons with African mona monkeys}

Morphometric data on African C. mona are limited (Table 6 ), but allow preliminary comparisons to be made with Grenada monas. With the exception of Clutton-Brock and Harvey (1977), the weights presented in the literature for adult male and female African mona monkeys show them to be sexually dimorphic, which mirrors our findings for $C$. mona on Grenada. The weights provided in the literature for both sexes of adult African mona monkeys overlap with those presented here, except for the weights reported by Chiarelli (1972) for males and Clutton-Brock and Harvey (1977) for females. Chiarelli (1972) reported male weights as reaching $6.0 \mathrm{~kg}$, while the heaviest male in our sample weighed $5.7 \mathrm{~kg}$. Clutton-Brock and Harvey (1977) reported a female weight of $4.5 \mathrm{~kg}$; the largest female in this study (an overfed pet) was $4.3 \mathrm{~kg}$.

Discrepancies between the morphometrics for African mona monkeys in the literature and those for Grenada C. mona are also found for body and tail length. Hill (1966), Chiarelli (1972), Grzimek (1975), Napier (1981), and Happold (1987) reported body lengths for adult males of $555 \mathrm{~mm}$, up to 645 $\mathrm{mm}$, up to $550 \mathrm{~mm}, 545 \mathrm{~mm}$, and up to 631 $\mathrm{mm}$, respectively. In contrast, the longest body length found in the Grenada mona sample among adult males was only 515 $\mathrm{mm}$. Chiarelli (1972) also reported adult female body lengths of up to $520 \mathrm{~mm}$, while the longest body length found in Grenada adult female mona monkeys was $422 \mathrm{~mm}$. Tail lengths for adult male African C. mona reported by Elliot (1912), Grzimek (1975), Napier (1981), and Happold (1987) were 785 $\mathrm{mm}$, up to $800 \mathrm{~mm}, 767 \mathrm{~mm}$, and up to 879 $\mathrm{mm}$, respectively. These lengths are much longer than the greatest tail length found for adult males in this study, which was 730 $\mathrm{mm}$. Finally, the largest tail length found for 
TABLE 6. Morphometrics of Cercopithecus mona in Africa

\begin{tabular}{|c|c|c|c|c|c|c|c|c|c|c|c|}
\hline \multirow[b]{3}{*}{$\mathrm{AM}$} & \multirow[b]{2}{*}{ Weight $(\mathrm{kg})$} & \multirow{3}{*}{$\overline{\mathrm{M} \text { and } \mathrm{F}}$} & \multirow[b]{3}{*}{$\overline{\mathrm{AM}}$} & \multirow{3}{*}{$\begin{array}{l}\text { Body } \\
\text { AF }\end{array}$} & \multirow[b]{3}{*}{$\mathrm{M}$ and $\mathrm{F}$} & \multicolumn{2}{|c|}{ Length ( $\mathrm{mm}$ ) } & & \multirow[b]{2}{*}{$\begin{array}{l}\text { Hind } \\
\text { foot }\end{array}$} & \multirow{3}{*}{$\begin{array}{l}\text { Fore } \\
\text { foot } \\
\mathrm{AM}\end{array}$} & \multirow[b]{3}{*}{ Source } \\
\hline & & & & & & & Tail & & & & \\
\hline & $\overline{\mathrm{AF}}$ & & & & & $\mathrm{AM}$ & $\mathrm{AF}$ & $\mathrm{M}$ and $\overline{\mathrm{F}}$ & $\overline{\mathrm{AM}}^{-}$ & & \\
\hline $3.6-5.5$ & $2.7-4.1$ & - & - & - & - & - & - & - & - & - & Booth 1960 \\
\hline- & - & $3.0-6.0$ & $415-645$ & $315-520$ & - & $575-1090$ & $480-1020$ & - & - & - & Chiarelli, 1972 \\
\hline 4.5 & 4.5 & - & - & - & - & - & - & - & - & - & Clutton-Brock and Harvey, 1977 \\
\hline- & - & - & 510 & - & - & 785 & - & - & 145.0 & - & Elliot, 1912 \\
\hline- & - & - & - & - & up to 550 & - & - & up to 800 & - & - & Grzimek, 1975 \\
\hline- & - & $2.5-5.5$ & - & - & $410-631$ & - & - & $635-879$ & -- & - & Happold, 1987 \\
\hline 4.4 & 2.5 & - & - & - & - & - & - & - & - & - & Harvey and Clutton-Brock, 1985 \\
\hline $4.63^{1}$ & - & - & $555^{1}$ & - & - & - & - & - & $136.7^{1}$ & $94.3^{1}$ & Hill, 1966 \\
\hline $2.73^{1}$ & & & $545^{1}$ & $419^{1}$ & & $767^{1}$ & $587^{1}$ & & & & \\
\hline (3) & - & - & (8) & (7) & - & 181 & (7) & - & - & - & Napier. 1981 \\
\hline 5.0 & 4.0 & _- & - & - & - & - & - & - & - & - & Takeshita, 1962 \\
\hline
\end{tabular}

Abbreviations: $\mathrm{A}$, adult; $\mathrm{M}$, male; $\mathrm{F}$, female. Numbers in parentheses are reported sample sizes.
${ }^{1}$ Mean value by reported sample size.

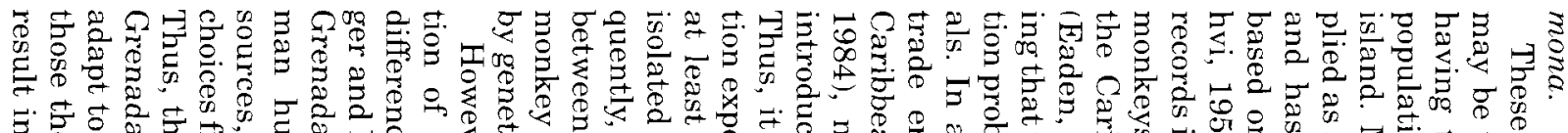

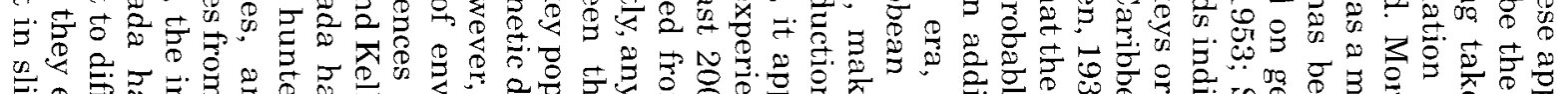

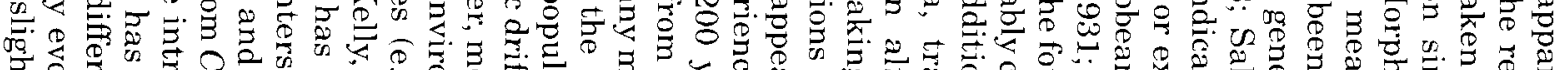

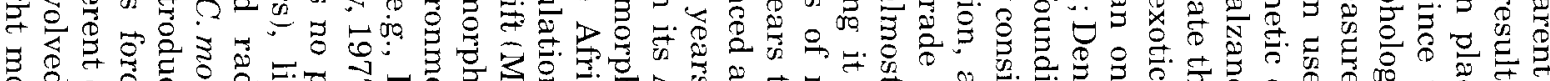

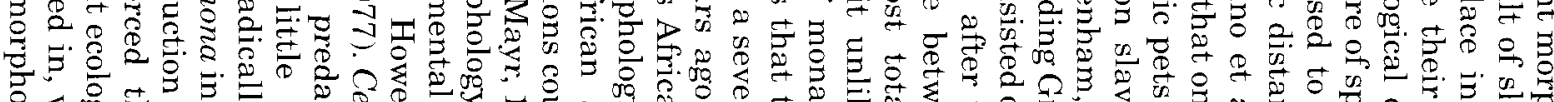

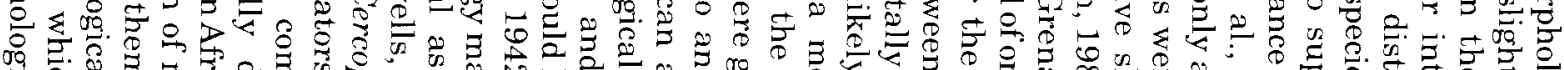

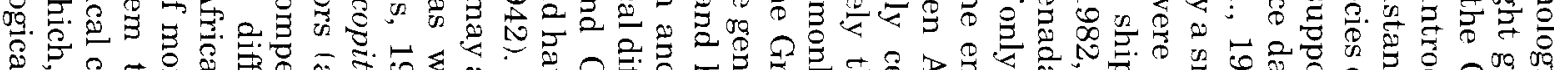

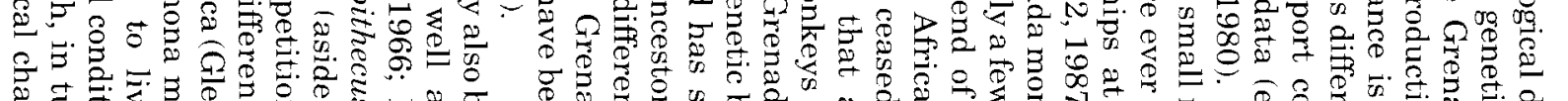

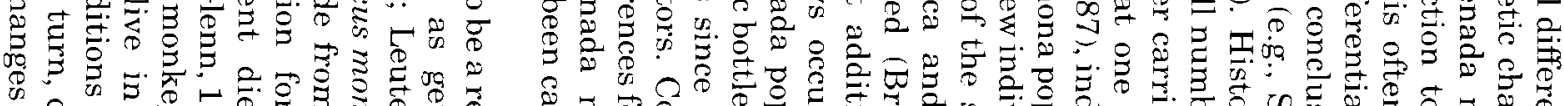

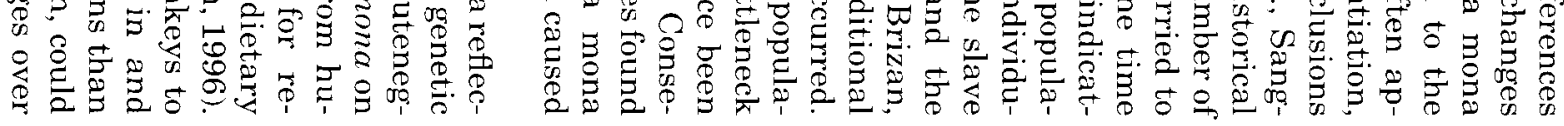

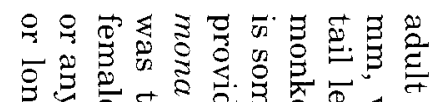

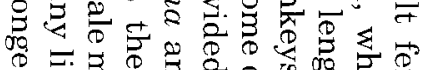

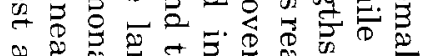
ह $\rightarrow$ के कै 20

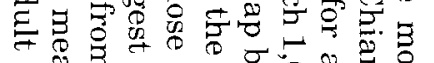
క气 (1)

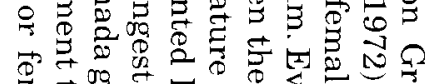

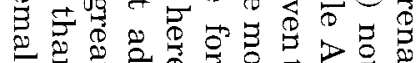

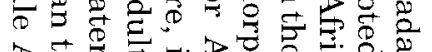

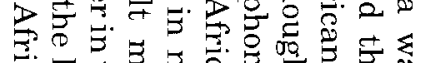

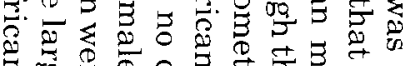

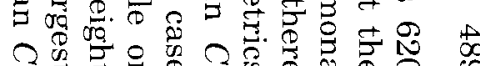


time occurring via natural selection or via differences in development resulting from growing up in differing environments.

It is premature, however, to attribute any apparent morphological disparities between C. mona on Grenada and in mainland Africa solely to genetic divergence or ecological adaptation. The differences found in weight, body length and tail length between our results and those reported in the literature for African mona monkeys may simply be a result of small sample sizes, or a reflection of the manner in which the data were collected. Many of the data available in the literature for C. mona in Africa came from museum collectors' field notes, and discrepancies may have arisen because of nonstandardized measuring methods. Unfortunately, none of the authors who reported linear measurements for African monas described how they were obtained, but simply gave measurement titles, such as "crown rump length" (e.g., Hill, 1966), or "head body length" (e.g., Chiarelli, 1972).

Finally, aside from the paucity of morphometric data on African monas in general and questions about data collection methods, it is not clear where the morphometrics in the literature were collected in Africa (Table 6), nor has the origin of the Grenada mona population been determined. If the Grenada population did not come from one of those African populations for which morphological data are available, no conclusions may be made regarding genetically or ecologically based changes because intraspecific variation could account for the apparent morphological differences. Additional morphometric data are needed from several populations of C. mona across their African range before meaningful comparisons may be made between Grenada and African mona monkeys, and conclusions drawn about the possible morphological divergence of the Grenada mona monkey population.

\section{ACKNOWLEDGMENTS}

We thank the Honorable Mr. Tillman Thomas and Ms. Lana McPhail of the Ministries of Tourism and Labour of the Government of Grenada, Mr. Michael Philip and Mr. Raymond Walker of the Grenada National Parks and Protected Areas, and Mr. Allan Joseph of the Grenada Forestry Department for the permission they generously granted to us to conduct research in the Grand Etang $\mathrm{Na}$ tional Park and Forest Reserve. We are grateful to Ms. Heather Bruce and Mr. Oscar "Chest" Andall for their assistance in the field, the members of the Grenada Wild Game and Conservation Association and the Grenada Fishing and Hunting Group for providing hunting information and access to hunted monkeys, all of the pet owners who graciously allowed us to anesthetize and measure their monkeys, Drs. Buxton Nyack and Brian Huntsman for their advice regarding anesthetics, and the members of the Grenada Society for the Protection and Care of Animals for their support. We also thank Dr. Malcolm Dow, Dr. Marian Dagosto, Dr. Brian Shea and several anonymous reviewers for their helpful criticism during the preparation of this manuscript, Dr. Ken Glander for his excellent darting advice, and Dr. Phyllis Lee for graciously allowing us to use her computer to run most of our statistical analyses.

\section{LITERATURE CITED}

Booth AH (1955) Speciation in the mona monkeys. J. Mammal. 36:434-449.

Booth AH (1956) The distribution of primates in the Gold Coatit. J. W. Afr. Sci. Assoc. 2:122-133.

Booth AH (1960) Small Mammals of West Africa. West African Nature Handbooks. London: Longmans.

Brett Fl, Turner TR, Jolly (S), and Cauble RG (1982) Trapping baboons and vervet monkeys from wild, free-ranging populations. J. Wildl. Manage. 46:164174

Brizan G (1984) Grenada: Island of Conflict. London: Zed Books.

Campbell AF, and Sussman RW (1994) The value of radio tracking in the study of neotropical rain forest monkeys. Am. J. Primatol. 32:291-301.

Chiarelli AB (1972) Taxonomic Atlas of Living Primates. London: Academic Press

Clution-Brock TH, and Harvey PH (1977) Primate ecology and social organization. J. Zool., Lond. 183 : $1-39$.

Denham WW (1982) History of the green monkey in the West Indies: Part 1. Migration from Africa. .J. Barbados Mus. and Hist. Soc. 36:211-228.

Denham WW (1987) West Indian green monkeys: Problems in historical biogeography. Contrib. Primatol. $24: 1-79$.

Eaden J (1931) The Memoirs of Pere Labat 1693-1705. London: Constable and Co.

Elliot DG (1912) A review of the primates. Vol. 2 of the Monographs of the American Museum of Natural History. New York: Museum of Natural History.

Frade F (1958) Aves e mamiferos das ilhas São Tomé e do Príncipe: Notas de sistematica e de protecẹão à fauna. Conferéncia International dos Africanistas OcidenLais, Communicações Zoologia e Biologia Animal 6 Sess., 4:137-150. 
Gautier-Hion A, and Gautier J-P (1976) Croissance, maturité sexuelle et sociale, reproduction chez les cercopithecines forestiers Africains. Folia Primatol. $26: 165-184$.

Glander KE, Fedigan LM, Fedigan L, and Chapman C (1991) Field methods for capture and measurement of three monkey species in Costa Rica. Folia Primatol. 57:70-82.

Glander KE, Wright PC, Daniels PS, and Merenlender AM (1992) Morphometrics and testicle size of rain forest lemur species from southeastern Madagascar. J. Hum. Evol. 22:1-17.

Glenn ME (1996) The Natural History and Ecology of the Mona Monkey (Cercopithecus mona Schreber 1774) on the Island of Grenada, West Indies. Ph.D. dissertation, Northwestern University.

Glenn ME (1997) Group size and group composition of the mona monkey (Cercopithecus mona) on the island of Grenada, West Indies. Am. J. Primatol. 43:167-173.

Glenn ME (in press) Population density of Cercopithecus mona on the Caribbean island of Grenada. Folia Primatol.

Glenn ME, and Bensen KJ (1993) Singes africains aux caraibes? Ou des Cercopithèques mones à Grenade. Espace Zool. Mag. 31:8-11.

Grzimek HCB (1975) Grzimek's Animal Life Encyclopedia, Vol 10. New York: Van Nostrand Reinhold.

Happold DCD (1987) The Mammals of Nigeria. Oxford: Clarendon Press.

Harvey PH, and Clutton-Brock TH (1985) Lif'e history variation in primates. Evolution 39:559-581.

Hill WCO (1966) Primates. Comparative Anatomy and Taxonomy VI. Catarrhini, Cercopithecoidea, Cercopithecinae. New York: Interspecies.

Horrocks JA, and Baulu J (1988) Effects of trapping on the vervet (Cercopithecus aethiops sabaeus) population on Barbados. Am. J. Primatol. 15:223-233.

Howells WW (1966) Population distances: biological, linguistic, geographical, and environmental. Curr. Anthropol. 7:531--535.

Jones W'T, and Bush BB (1988) Darting and marking techniques for an arboreal forest monkey, Cercopithe (rus ascanius. Am. J. Primatol. 14:83-89.

Leigh SR (1994) Relations between captive and noncaptive weights in anthropoid primates. Zoo Biol. 1:3: $21-43$.

lemos de Sa RM, and Glander KE (1993) Capture techniques and morphometries for the woolly spider monkey, or muriqui (Brachyteles arachnoides, E. Geoffroy 1806). Am. J. Primatol. 29:145-153.

Leutenegger W, and Kelly JT (1977) Relationship of sexual dimorphism in canine size and body size to social behavioral and ecological correlates in anthropoid primates. Primates 18:117-136.

Mayr E (1942) Systematics and the Origin of Spccies. New York: Columbia University Press.

Müller K-H, and Schildger J (1994) Capture and radiotelemetry of masked titi monkeys, Callicebus personatus melanochir: Neotrop. Primates 2:7-8.

Nadler RD, and Rosenblum LA (1972) Hormonal regulation of the 'fatted' phenomenon in squirrel monkeys. Anat. Rec. 173:181-188.

Napier PH (1981) Catalogue of Primates in the British Museum (Natural History) and elsewhere in the British Isles. Part II: Family Cercopithecidae. Subfamily Cercopithecinae. London: British Museum (Natural History).

Oates JF (1988) The distribution of Cercopithecus monkeys in West African forests. In A Gautier-Hion, F Bourlière, J-P Gauticr, and J Kingdon (eds.): A Primate Radiation: Evolutionary Biology of the African Guenons. Cambridge: University Press, pp. 79-103.

Pearl MC (1982) Networks of Social Relations Among Himalayan Rhesus Monkeys (Macaca mulatta). Ph.D. dissertation, Yale University.

Salzano FM, Callegari-Jacques SM, Franco MHLP, Hutz MH, Weimer TA, Silva RS, and Da Rocha FJ (1980) The Caingang revisited: Blood genetics and anthropometry. Am. J. Phys. Anthropol 53:513-524.

Sanghvi LD (1953) Comparison of genetical and morphological methods for a study of biological differences. Am. J. Phys. Anthropol 11:385-404

Savage A, Giraldo LH, Blumer ES, Soto LH, Burger W, and Snowdon CT (1993) Field techniques for monitoring cotton-top tamarins (Saguinus oedipus oedipus) in Columbia. Am. J. Primatol. 31:189-196.

Scott Jr NJ, Scott AF, and Malmgren LA (1976) Captur ing and marking howler monkeys for field behavioral studies. Primates 17:527-533.

Struhsaker 'TT (1969) Correlazes of ecology and social organization among African cercopithecines. Folia Primatol. $11: 80-118$.

Takeshita $\mathrm{H}$ (1962) On the delivery behavior of squirrel monkeys (Saimiri sciurea) and a mona monkey (Cereopithecus mona). Primates 3:59-72 